\title{
Trench fever: the British medical response in the Great War
}

\author{
R L Atenstaedt
}

J R Soc Med 2006;99:564-568

\section{INTRODUCTION}

In mid-1915, the medical officer Major J H P Graham made this important observation from the Western Front:

'A private belonging to an infantry regiment was admitted to a casualty clearing station from a field ambulance where he had been detained suffering from a febrile illness of three days' duration and of sudden onset.' 1

The characteristics of this condition were unlike anything that he had previously encountered: 'the patient's condition on admission was marked by frontal headache, dizziness, severe lumbago, a feeling of stiffness down the front of the thighs, and severe pains in the legs referred chiefly to the shins. ${ }^{1}$ One of the most curious qualities was the relapsing fever.

The Commanding Officer of No. 5 Canadian Mobile Laboratory alerted both the advisor in pathology to the British Expeditionary Force (Sir William Leishman) and the consulting physician to the 1st Army (Sir Walter Herringham). Both clinicians conducted an extensive investigation, reviewing cases of the disease and interviewing colleagues in France. Leishman drafted a short report to his boss, the Director-General of Medical Services (DEMS) in France, Sir Arthur Sloggett. ${ }^{2}$ He reported: 'I concur to some extent in Sir W Herringham's view that it is a separate and hitherto unrecognized disease ...'2

In spite of this view being expressed by both Leishman and Herringham (senior members of the military-medical authorities), there continued to be a lively debate in the medical press over whether trench fever was indeed a new disease or an old one in a new guise. Some doctors hypothesized that the illness might be one of the enteric group of fevers, modified by preventive inoculation, such as that given for typhoid. ${ }^{3}$ However, Captain G H Hunt and Major A C Rankin, pathologists employed in a mobile laboratory, disagreed vehemently with this view. ${ }^{4}$ They, along with a growing number of medical officers, believed that the cause was a specific organism that had never

National Public Health Service for Wales and Institute of Medical \& Social Care Research (IMSCaR), University of Wales, Bangor, Wales, UK

Correspondence to: Institute of Medical \& Social Care Research, Ardudwy, Normal Site, University of Wales, Bangor, Gwynedd LL57 2PX, Wales, UK

E-mail: Robert.Atenstaedt@nphs.wales.nhs.uk previously been recognized. ${ }^{4}$ Support for their theory was provided by laboratory studies:

'It was not until hundreds of cases had been examined in laboratories up and down the line that we could accept it as certain that there was a short fever that was not enteric. ${ }^{5}$

Trench fever was finally accepted as a clinical syndrome that occurred with enough consistency and frequency to justify its classification as a specific disease. Ultimate authority was lent to this view when the authorities moved to officially recognize the novel condition in the summer of $1916 .{ }^{6}$

\section{SEARCH FOR A CAUSE}

There was a vigorous debate around the aetiology of the condition. From the beginning of the conflict, an infective theory dominated, as the disease was closely associated with a fever, the cardinal sign of infection. Trench fever, as a relapsing fever, shared similarities with malaria. From work done by Ronald Ross in 1898, malaria was known to have a vector (the Anopheles mosquito) and a causative agent. ${ }^{7}$

As a result of observations on cases in a stationary hospital, Captain $\mathrm{T}$ Strethill Wright postulated that the condition might be carried by one of the common flies or parasites found in the trenches. ${ }^{8}$ The most likely culprit, in his opinion, was the body louse. This was because the disease was especially prevalent during the winter, when mosquitoes and flies were absent from the trench environment. Hunt and Major J W McNee provided very convincing epidemiological evidence in favour of the louse as vector. ${ }^{9}$ The case for louse transmission was further strengthened by powerful, albeit anecdotal evidence. Major A F Hurst, for instance, described a situation where a 'lousy' sergeant had transmitted the disease to six of his compatriots. ${ }^{10}$

In spite of the strong candidature of the louse, other agents were proposed. Lieutenant W J Rutherford, for example, suggested that the common field vole or mouse might transmit the disease. ${ }^{11}$ Another dissenter, Captain B Hughes, claimed that trench fever might be the result of a rat-derived infection, combined with constipation. ${ }^{12}$

There were those who completely ruled out an infectious cause for the disease. Belief in the influence of climate in disease causation had persisted in the medical 
profession. ${ }^{13}$ From his vantage point in the spa town of Harrogate, retired Army Medical Service Colonel M D O'Connell wrote to the Lancet in 1915, proposing the atmospheric environment of the trenches as a possible cause of the fever. ${ }^{14}$ He wrote again to the same journal in October, citing further evidence to support his theory, including temperature readings. ${ }^{15}$ However, both these letters failed to produce a reaction. This is not surprising, as a narrow belief in climatic causes was not part of the new medical orthodoxy that looked for specific organisms as agents of causation for specific diseases.

There were also a large group of doctors who understood germ theories, but retained a belief in the influence of locality on the causation of infectious disease. In November 1916, Captain J Muir's report on trench fever was published. ${ }^{16} \mathrm{He}$ had analysed the 'admission-anddischarge' books of the three field ambulances in his division and found that the disease peaked in July-August, OctoberNovember and January-February. He made the important observation:

'The only factors common to the three periods were the extreme strain and exposure in the trenches or of other activities necessarily associated with "holding the line", 16

In his opinion, therefore, trench fever might be due to some infecting agent, 'ubiquitous in its distribution'; perhaps localized in the nasopharynx, with the determining factor being the resistance of the individual to infection.

By the end of 1916, most had concluded the human louse transmitted trench fever, as this was the most common blood-sucking insect in the trenches. However, definitive experimental proof was lacking.

In the middle of 1917, a committee was set up to study trench fever in France, titled the BEF PUO (British Expeditionary Force Pyrexia [fever] of Unknown Origin) Enquiry Sub-committee. At the first meeting of the medical research committee of the American Red Cross in October 1917, a decision was made to devote the considerable resources of this organization to investigating a medical problem affecting the Allies. It is a testimony to the importance of trench fever that it was chosen to be the research topic. The British gave them control over the two key research areas - the disease's method of transmission and the infective properties of the blood. ${ }^{2}$

Simultaneously, a concerted campaign was undertaken by the BEF's scientific advisors to persuade the War Office (WO) to fund a special research committee on trench fever in Britain. ${ }^{17}$ The WO Trench Fever Investigation Commission used laboratories in the Medical Research Committee's hospital at Hampstead and was given authority to obtain civilian volunteers for human experimentation.
From the end of 1917, both the BEF PUO Enquiry (aided by the Americans) and the WO Trench Fever Investigation Commission went ahead at full stretch: 'The two campaigns were carried out in a spirit of mutual cooperation, combined with a wholesome tang of competition - the ideal atmosphere for scientific creation. ${ }^{\text {' }}{ }^{17}$

The American research team performed a number of lice transmission experiments at their base in France, using American volunteers. Their findings were presented in the BMJ in August 1918:

'The disease ... can be conveyed by the bites of the louse alone, as well as by other means. . . Infection appears to be conveyed by such bites for at least twelve days after the louse has ceased to feed on a patient with trench fever.' 18

The WO Trench Fever Investigation Commission began their investigations in December 1917, concluding that the louse was the conveyer of the disease. However, the bite of the louse was an unusual means of infection, the more common one being the rubbing of infected louse excreta onto irritated skin. In fact, the British were to be proven correct. Major H Plotz admitted in the official history of the medical department of the US army that direct entry of the organism through biting occurred only infrequently. ${ }^{19}$

Concurrent with research into the vector of trench fever, investigations were also being pursued to discover the causative agent of the disease. One study group managed to isolate a 'micrococcus. ${ }^{20}$ Another found an enterococcus in the urine of convalescent soldiers. ${ }^{21}$ Major T Houston and Captain J M McCloy also managed to isolate the same organism. ${ }^{22}$ However, this finding was disproven: 'In view of the multitude of sterile cultures by other workers [Houston's] finding must be considered accidental.' 23 At the end of 1917, an article appeared in the Lancet by Captain L Dimond. ${ }^{24}$ This described his analysis of venous blood from cases of trench fever, enabling him to locate a haemogregarine (a type of protozoan). However, as a result of meticulous confirmatory bacteriological work, organized by Leishman, a protozoan cause for trench fever was soundly discredited. Another microbial cause put forward was the spirochaete. ${ }^{25}$ Further research, however, established that these microbes could be easily found in the urine of many non-diseased soldiers. American investigators working in France discovered a novel type of organism in the blood of cases, provisionally assigning it to the genus Piroplasma. ${ }^{26}$ However, the lead researcher later published an apologetic letter, in which he admitted that these bodies were in all probability not living organisms. ${ }^{27}$

Investigators were unsuccessful in proving that either bacteria or protozoa were the cause of trench fever. However, as a result of work carried out by the WO Trench Fever Investigation Commission, Rickettsia (small 
bacteria which only replicate within another cell), became the most likely candidate. Bodies resembling diplococci had been found by $\mathrm{H}$ T Ricketts ${ }^{28}$ in the blood of patients and in the insect vector transmitting Rocky Mountain Spotted Fever. The German H Töpfer had discovered that lice fed on trench fever sufferers contained a large number of these 'Rickettsial bodies'. ${ }^{29}$ In Britain, Arkwright et al. found that if lice were allowed to feed on trench fever patients, and the excreta of these insects collected after a period of three days, the same organisms could be observed. ${ }^{30}$ However, normal lice, which had been fed on healthy subjects, remained free of them. The researchers were also able to show a close correlation between the presence of Rickettsial bodies in lice excreta, and its virulence when inoculated into humans. Here, then, was a proven, novel causative agent (the Rickettsia) to account for a new disease (trench fever).

\section{LABELLING}

When the condition first arose, articles appeared in the medical press of several nations reporting the disease under different names: 'La Fèvre des Trancheés' and 'Typhus Mineur'2 (France), 'Wolhynian Fever' (Germany) ${ }^{29}$ and 'Gaiter-Pain' fever (Austria). ${ }^{17}$ In the British forces, the tag 'trench fever' was originally coined by the troops. The term 'trench fever' was first used by Hunt and Rankin in November 1915. They considered that it seemed to fit the disease well, as it was confined to the trench area. ${ }^{4}$ Hunt and McNee subsequently admitted that the fever was no longer confined to the trench zone. ${ }^{9}$ They argued that this was due to the disease spreading down the lines of communication, but, as it had originally arisen in the trenches, the term 'trench fever' remained valid. In August 1916, the DGMS, acting on advice received from the consulting physicians, recommended to the WO that the label 'trench fever' be used, until a more scientific nomenclature based upon pathological data was assigned. ${ }^{6}$ The WO officially assigned the name 'trench fever' to the disease at the end of $1917 .{ }^{31}$

\section{THE THREAT}

Trench fever was first reported among the British forces in Flanders during the summer of 1915. Among the rank-andfile, the condition was not regarded as a great scourge. Indeed, it afforded men valuable rest from the hardships of campaigning. However, the soldiers' lack of concern was not shared by General Headquarters, as the disease incapacitated large numbers of men in a type of combat that relied on maximizing fighting strength. This severe wastage provided a strong impetus for the medical response:
'Trench fever is a matter of national importance . . . and it merits the attention of every physician and pathologist who has the opportunity of working among the troops. 32

No records on incidence of trench fever were kept by the authorities, due to a lack of reliable figures. ${ }^{33}$ Sir David Bruce reported in 1922 that there were over one million cases among the Allies on the Western Front; ${ }^{34}$ this number is reproduced in a recent article on the disease ${ }^{35}$ and by Arno Karlen. ${ }^{36}$ Yet are Bruce's one million cases feasible? He stated that these occurred among the Allies - British Empire, French, Belgian and American troops. If the Americans, who entered the war in 1917 and reported only 743 cases among their troops, ${ }^{37}$ are excluded, then this leaves 5400000 British Empire, ${ }^{38} 8400000$ French $^{39}$ and 270000 Belgium $^{39}$ soldiers in France and Belgium. If one assumes that the million cases were distributed equally amongst these forces, this would give 380000 in the BEF. Major A G Butler provides further evidence in support of a figure of this magnitude. ${ }^{17}$ He stated that the average evacuation for sickness in France was approximately $0.6 \%$ of army strength weekly, and in 1917 trench fever constituted $15 \%$ of this total $(0.09 \%)$. There were 5400000 British Empire troops (59 divisions) in the trenches from December 1916 until November 1918, with 26 divisions (2 $700000 \mathrm{men}$ ) prior to this. Wastage from trench fever was reduced in the final year of the war, as anti-lice measures were introduced. If one assumes that the sickness rate in 1918 was half the 1917 figure (0.045), then in the 3 years that the disease was prevalent, from the summer of 1915 until the War's end, there were approximately 0.09 / $100 \times 52 \times 2700000+0.09 / 100 \times 52 \times 5400000+0.05 /$ $100 \times 52 \times 5400000=520000$ cases. The two estimation methods produce broadly similar results, indicating overall validity. If Bruce's figure of over one million casualties among the Allies is considered, then it appears valid to take an average of these two figures: 380000 and $520000=450000$. This, then, may be the best estimate for the total number of cases of trench fever sustained by the British Army in the War.

Morbidity rates alone do not reveal the full extent of trench fever's debilitating effect on soldiers, many of whom became chronic sufferers. In 1920, 6000 men in Britain still attributed their war disability to trench fever and were a continuing financial burden to the State, which had to pay their pensions. ${ }^{40}$

\section{TREATMENT}

When medical officers first tried to treat trench fever, they used those medicaments that they had nearest to hand: those they carried in their standard issue drug boxes. One of these, quinine, was the first drug reportedly used to treat 
the condition. ${ }^{4}$ To Hunt and Rankin, it seemed a sensible choice, as it was known to be effective against malaria, also a recurring fever. However, it had no effect on the natural course of the disease. Salvarsan had been developed as a specific against syphilis. In No. 2 London Casualty Clearing Station, Hunt and McNee made an unsuccessful attempt to treat trench fever with this drug plus antimony. ${ }^{9} \mathrm{~J}$ E Sweet and J B Wilmer used another substance, collargol, ${ }^{41}$ which they believed to be effective, though another officer cast doubt on this drug in a subsequent letter. ${ }^{42}$ The report of the WO Trench Fever Investigation Commission described the many attempted drug therapies: acriflavine, galyl, intramine, kharsivan, methylene blue and trypan red. ${ }^{43}$ Researchers were also unsuccessful in curing the disease by using a vaccine - injecting an emulsion of louse excreta, sterilized by heat or phenol.

As specific cures proved non effective, clinicians resorted to physical methods. For example, Major A J H Iles used electrotherapeutics to treat a complication of trench fever, shin pain, passing an electrical current through the affected leg. ${ }^{44}$ By their second visit, he claimed that his patients had gained almost total pain relief and there was no tendency to recurrence.

\section{PREVENTION}

The most important weapon against trench fever was direct action against the parasitic cause. Lice were a serious problem in the trenches, as men were huddled together in large numbers in unsanitary conditions.

Research into the lice problem involved intensive scrutiny of the life history of the insect. Lieutenant A D Peacock, for example, examined a number of units in France, concluding that blankets, straw and dugouts were infrequent sources of lice, the most important being the men themselves. ${ }^{45}$

The WO published a list of recommendations designed to minimize louse infestation, known as Department of Government Circular Memorandum No. $16 .{ }^{46}$ In theory, men were stripped and their clothing rigorously examined, at least weekly. However, the Official History of the WarMedical Services admitted that adequate routine medical inspection of healthy troops was an impossibility.' 46 The Army also established divisional baths to turn lice-ridden men into clean soldiers, with the aim being to wash every man at least once every 2 weeks.

At the beginning of the conflict, there was no large-scale method of disinfestation available, other than a small number of horse-drawn 'thresh steam disinfectors', originally designed for the sterilization of clothes that had been exposed to infectious disease. The 'Russian Pit' hot air delouser, with a far larger capacity, did not reach the
Western Front until June 1918, after its importance had been brought to the attention of the Advisory Council.

Chemical insecticides against lice were also developed, both in France and in the UK. A W Bacot (entomologist at the Lister Institute) was sponsored by the WO to carry out research on these agents. ${ }^{47} \mathrm{He}$ found NCI (naphthalene $96 \%$, creosote $2 \%$ and iodoform $2 \%$ ) to be the most potent chemical, and went on to develop a paste that could be spread on the seams of tunics and would kill lice within 2 hours.

When the soldiers were demobilized at the end of the War, the authorities were determined that trench fever would not reach Britain. Elaborate disinfestation stations were established at Boulogne, Calais, Rouen, Le Havre, Dunkirk and Dieppe. At each location, men were stripped and had their kit thoroughly disinfested. As a consequence of these measures, the disease did not spread to the civilian population in Britain. ${ }^{46}$

\section{CONCLUSION}

The response to trench fever was effective once the condition had been recognized as a specific, new disease. The medical profession was able to identify a vector, the louse, which was later proved to transmit the disease. It has been argued that this was one of the original contributions of the war period. ${ }^{48}$ The eradication of lice helped to reduce the prevalence of the disease. The identification of the Rickettsia (a new type of organism) as the causative agent was equally laudable. However, the response had its limitations.

First, no cure for trench fever was found and the disease continued to be a severe drain on army manpower throughout much of the conflict.

Secondly, it was recognized that thorough investigation had been carried out too late:

'This is a striking example of research work which, if carried out at the beginning of the war instead of at the end, might have saved the Allied Armies hundreds of thousands of cases of disease. ${ }^{49}$

The third shortcoming, it could be argued, is that it was a waste of resources to have had two committees, one British and one American, researching the same condition. However, Bruce noted that the number of experimental subjects was limited and the work of one committee had served to supplement the other. ${ }^{34}$

Trench fever has not gone away; in the last decade it has re-emerged as 'urban trench fever' in populations of the homeless and alcoholics, the causative organism now renamed Bartonella quintana. ${ }^{50}$ However, the body louse 
still lies at the root of the problem, as it did in the trenches of the Great War.

Acknowledgments I would like to thank Dr Sandra Payne and the staff of the National Public Health Service for Wales; also Professor Ian Russell and those at the Institute of Medical \& Social Care Research (IMSCaR), University of Wales, Bangor. I would also like to thank the Wellcome Trust for providing me with a grant to visit archives. This research formed part of a DPhil at Oxford University, supervised by Professor Paul Weindling.

Competing interests None declared.

\section{REFERENCES}

1 Graham JHP. A note on a relapsing febrile illness of unknown origin. Lancet 1915;ii:703-4

2 The National Archive. WO 95/3983. Lines of Communication: Diary of Pathological Advisor, October 1914 - January 1919, 3 August 1915, 4 August 1915, 25 January 1918 and 10 August 1915

3 Robinson H. So-called trench fever. Lancet 1915;ii:1214

4 Hunt GH, Rankin AC. Intermittent fever of obscure origin occurring among British soldiers in France. The so-called "trench fever". Lancet 1915;ii:1133-6

5 Herringham WP. On trench fever and its allies. QJ Med 1915-16;9: 429-32

6 The National Archive. WO 95/45. General Headquarters: Diary of Director-General Medical Services, January 1916-December 1916, 3 August 1916

7 Harden V. Rocky mountain spotted fever research and the development of the insect vector theory, 1900-1930. Bull Hist Med 1985;59:449-66

8 Strethill Wright T. Some notes on trench fever. BMJ 1916;2:136-8

9 Hunt GH, McNee JW. Further observations on trench fever. QJ Med 1915-16;9:442-9

10 Hurst AF. Trench fever: a relapsing fever amongst the British troops in France and Salonica. Lancet 1916;ii:671-5

11 Rutherford WJ. Trench fever: the Field Vole a possible origin. BMJ 1916;2:386-7

12 Hughes B. Trench pyrexias; their prevention and treatment. Lancet 1916;ii: 474

13 Davidson A. Geographical Pathology: An Inquiry into the Geographical Distribution of Infective and Climatic Diseases, Vol.1. Edinburgh: Young J Pentland, 1892

14 O'Connell MD. "Trench fever". Lancet 1915;ii:1368-9

15 O'Connell MD. Atmospheric conditions in relation to trench fever. Lancet 1916;ii:767

16 Muir J. "Pyrexia" or "trench fever". BMJ 1916;2:641-5

17 Butler AG. The Australian Army Services in the War of 1914-18, Vol.1. Canberra: Australian War Memorial, 1943

18 Anon. The etiology of trench fever. BMJ 1918;2:120

19 Plotz H. Vermin Infestation and Delousing. In: Ireland ML (ed). Medical Department of the United States Army in the World War, Vol. 6. Washington: Department of the US Army, 1926:372-413

20 Birks AH, Thornley RT, Fawcus, RA. Septicaemia due to micrococcus tetragenis as a cause of pyrexia at the front. QJ Med 1917-18;10:1-6
21 Darling G, Wilson WJ. Enterococcus in the urine of convalescent soldiers. Lancet 1916;ii:804

22 Houston T, McCloy JM. The relation of the enterococcus to "trench fever" and allied conditions. Lancet 1916;i:636-7

23 MacPherson WG, ed. Official History of the War-Medical ServicesPathology of the War. London: HMSO, 1921-3

24 Dimond L. Trench fever, or P.U.O. associated with the presence of a haemogregarine. Lancet 1917;ii:382-4

25 McCrea HM. Trench fever. Is this condition a spirochaetosis? Lancet 1917;i:796

26 Pappenheimer AM, Vermilye HM, Mueller JH. On the etiology of trench fever (a preliminary contribution). BMJ 1917;2:474-6

27 Pappenheimer AM. The etiology of trench fever. BMJ 1917;2:568

28 Ricketts HT. A micro-organism which apparently has a specific relationship to Rocky Mountain Spotted Fever. JAMA 1909;52:379-80

29 Töpfer H. Zur aetiologie de "Febris Wolhynica". Berl Klin Wochen 1916;53:323-4

30 Arkwright JA, Bacot AW, Martin Duncan F. The association of Rickettsial Bodies in lice with trench fever. BMJ 1918;2:307

31 Wellcome Library. RAMC/728/2/15. Instructions for MOs i/c works, fo.1

32 Sundell CE, Nankivell AT. Trench fever. Lancet 1918;i:399-402

33 Mitchell TJ, Smith GM. Official History of the War-Medical ServicesCasualties and Medical Statistics. London: HMSO, 1931

34 Bruce D. Trench fever: final report of the War Office Trench Fever Commission. J Hygiene 1921-22;20:258-88

35 Relman DA. Has trench fever returned? NEJM 1995;332:463-4

36 Karlen A. Man and Microbes. Disease and Plagues in History and Modern Times. New York: Simon \& Schuster, 1995

37 Ireland ML, ed. Medical Department of the United States Army in the World War, Vol. 15. Washington: US Army, 1926

38 The Expansion of the Army [cited 2002 June 15] [http://www.19141918.net/growth.htm l]

39 Armies 1914 [cited 2002 June 15] [http:// www.spartacus.schoolnet.co.uk/FWWarmies1914.htm]

40 MacPherson WG. Trench Fever. In: his Official History of the WarMedical Services - Diseases of the War, Vol. 1. London: HMSO, 1921-3: $358-73$

41 Sweet JE, Wilmer HB. A treatment for trench fever. Lancet 1919;i: 252

42 Lloyd JH. Colloidal silver in trench fever. Lancet 1919;i:583

43 Byam W. Trench Fever - a Louse Borne Disease. London: Oxford University Press, 1919

44 Iles AJH. Treatment of painful shins following trench fever by electrotherapeutic methods. BMJ 1917;2:484

45 Peacock AD. The louse problem on the western front. J R Army Med Corps, 1916;27:31-60

46 MacPherson WG. Prevention of Infestation by Lice. In: his Official History of the War-Medical Services-Hygiene of the War, Vol. 2. London: HMSO, 1921-3:327-88

47 Bacot AW. The use of insecticides against lice. BMJ 1916;2:447

48 Garrison FH. Notes on History of Military Medicine. Washington: Association of Military Surgeons, 1922

49 Bruce D. Prevention of disease. Nature 1924; Suppl.:213-27

50 Karem KL, Paddock CD, Regnery RL. Bartonella henselae, B. quintana, and $B$. bacilliformis: historical pathogens of emerging significance. Microbes Infect 2000;2:1193-205 